DE DE GRUYTER OPEN
Journal of Intercultural Management

Vol. 6, No. 4, December 2014, pp. 203-214

DOI 10.2478/joim-2014-0046

\author{
Magdalena Olkowicz \\ Warsaw University of Life Sciences - SGGW \\ Emilia Grzegorzewska* \\ Warsaw University of Life Sciences - SGGW
}

\title{
Eco-design as a strategic way to competitiveness in global markets for furniture family-owned MSMEs
}

\begin{abstract}
The furniture industry is a traditional Polish industry branch where the vast majority of firms are exactly MSMEs. Moreover the majority of them are family firms1. Their owners and managers with limited marketing budgets, more than large one, need a clear set of guidelines to compete in the global market. Environmental impacts for furniture are minor during use, and more associated with production and disposal. This paper demonstrates that using a method of eco-design and implementing ecoinnovation within the framework of a new product strategy can be successful, even though resources are limited. For the purpose of present the possible opportunities and barriers of eco-design implementation the literature study was conducted. According to the results growing concern about the environmental effects derived from furniture production and products use as well as on how they are disposed of at the end of their life cycle may in some degree determine the company market position. To compete successfully on global markets furniture family-owned MSMEs should take intent steps, and eco-trends indicate not only the most popular, but also desired by consumers direction.
\end{abstract}

Key words: furniture, eco-design strategies, review, family business, MSMEs

\footnotetext{
1 A family enterprise is each business from the MSME sector, regardless of the legal form, registered and operating in Poland, in which: at least two family members working together, at least one family member has a considerable impact on managing the enterprise, family members have a significant share in the enterprise [PAED 2009, p. 48].
}

\footnotetext{
* emilia_grzegorzewska@sggw.pl
} 


\section{Introduction}

MSMEs are increasingly seen as an important focus for the attention of policymakers. In Europe when trade barriers fell, companies, especially from MSMEs ${ }^{2}$ sector, must be much more competitive to survive [WBCSD 2006, p. 35]. The furniture industry is a traditional Polish industry branch where the vast majority of firms are exactly MSMEs and which globally represent a relatively great proportion of the national trade and employment. In fact, the most of them are family firms employing frequently from two to nine people. The furniture manufacturing is considered as a typical low-tech affair according the European Furniture Manufacturers Federation, where innovation is fundamentally based on adoption more than invention. The shortage of resources in the companies to develop radical innovations, caused that they do not have a way to protect them since counterfeiting is so easy [Hoffman et al. 1998, p. 39; Otero-Neira et al. 2009, pp. 220].

Furniture manufactured in Poland for decades contribute to ongoing development that industry branch. Therefore, Poland is now one of the world's top furniture manufacturers [Grzegorzewska E., 2013, p. 308]. To keep competitive position on the market by Polish furniture, manufacturers have to care about continual development of their companies. However improvements, that appear most often, i.e. made only on a production level (technological or process innovation), could be not sufficient. It becomes necessary to initiate implementation of enhancement in an earlier stage, it means in the new (or innovative) product development process [Grzegorzewska E. and Olkowicz M., 2013, p. 299]. It is known that there are several factors that significantly determines the way of its realization, e.g. a sector of the economy, an industry type, specificity and nature of production, strategies and a company size [Olkowicz M. and Szymanowski W., 2012, pp. 118-122]. Nevertheless the process of developing a new product does not depend so much on the level of technological complexity of the implemented product as on the quality of management and the competence of the staff who supervise the development process [Lindman et al. 2008, p. 52]. So regardless of the company size and the type of an industry (low- or high-tech) in order to improve the efficiency of the new product development process and obtain (or keep) market position, each enterprise requires an approach which enable it to find some competitive advantages. As claim Lassen et al. [2008, p. 93], furniture MSME owners and managers with limited marketing budgets, more than large one, need a clear set of guidelines to compete in the global market, and they must overcome their reluctance to allocate resources to leveraging their brands. This paper demonstrates that using a method of eco-design and implementing eco-innovation within the framework of a new product strategy can be successful, even though resources are limited. For the purpose of present the possible opportunities and barriers of eco-design implementation the literature study

"MSME" is defined as a firm with less than 250 employees. 
was conducted. Deeper knowledge of the environmental impacts of the materials and processes used in the furniture industry, as well as awareness of the customers' criteria for ecological furniture enable companies to 'green' their products and gain win recognition on the market [Parikka-Alhola K. 2008, p. 473]. This is requirement of the present and near future because consumers are becoming increasingly conscious about the products they purchase and manufacturers and retail chains cannot ignore this [Çinar H. 2005, p. 27].

\section{Innovativeness in family-owned MSMEs}

A successful company is conditioned not only by the organization capacity to determine market needs. The firm must also find the best way of satisfying customers through competitively viable offers. Innovation is perhaps the tool to achieve such offers [Otero-Neira et al. 2009, pp. 216-217].

Innovation is one of the most important strategies of competition, both for small and large firms. It is often argued that MSMEs innovate in specific ways, different from the innovation process in large firms. Regarding innovative performance, the heterogeneity is caused by a mix of factors. The most important are: the technological level (high-tech firms are usually more active in product innovation), the market relations (innovator attracts customers attention) and the strategies of competition (competition based on improved quality and new functions rather than reducing prices) [Kaufmann A. and Tödtling F. 2002, p. 147]. The factors affecting the different stages of the innovation process can play a significant role through their effect on the economic performance of a sector and its interactions to the related business environment [Trigkas, et al. 2012, p. 155]. In many cases in MSMEs sector, especially in family businesses, the barrier is more of a management than a technical (or financial) problem. Environmental problems tend to be generated by a lack of good management in all areas, so such problems cannot be fixed by a technical change here or there [Carlson et al. 2006, p. 531; WBCSD 2006, p. 36]. Kaufmann and Tödtling [2002, p. 157] also noticed that human resources is important factor for small firms on the way to innovations. In their opinion they used more intensively manpower than large firms, what indicates the need of engagement more adequately qualified people. Surprisingly, bottlenecks regarding human resources - lack of qualified personnel, technical knowhow, and time - were rarely indicated by the firms. In Poland the case concerns a large group of enterprises because family businesses constitute $36 \%$ of MSME. It can be estimated that family enterprises belonging to the MSME sector produce at least 10,4\% of total Polish GDP (more than PLN 121 billion). Moreover family enterprises in Poland employ circa 1 million 300 thousand persons, which constitutes about $21 \%$ of the total number of employees in MSME sector [PAED 2009, p. 21]. 
Sustained innovativeness depends on each firm's set of dynamic capabilities, which helps it integrate, build, and reconfigure internal and external competencies to address rapidly changing environments by activating, copying, transferring, synthesizing, reconfiguring, and redeploying different skills and resources [Branzei and Vertinsky, I. 2006, p. 77]. To compete successfully on global markets, MSMEs must build strong market positions. Brand differentiation can help firms to increase their market power and prices in the long run if earlier they create the necessary conditions, i.e. identify the brand essence, focus on the right target group and keep all communication and market activities consistent and continuous [Lassen et al. 2008, pp. 102-104]. Choosing eco-design as the brand essence could be successful for MSMEs.

\section{Eco-design strategies}

The widespread globalization of goods and services is prompting companies in industrialized nations to adopt innovation and creativity strategies to ensure their growth. Eco-design, therefore, can be seen as a response to this situation, combining creativity, innovation and environmental responsibility [Plouffe et al. 2011, p. 573].

Multiple meanings of the term eco-design can be found in the literature. For example, eco-design as an activity which focuses on the integration of environmental considerations into product development, and that eco-design tools ought to be made available to designers during the product development process [Bovea and Pérez-Belis, 2012, p. 61]. By 'eco-design' also is meant the systematic and consistent strife for improving the environmental profile of product(s) in all stages of the product life cycle, including proper recycling and disposal [van Hemel and Cramer 2002, p. 440]. Moreover sometimes eco-design is referred as Design for Environment (DfE), that is an umbrella term describing techniques used to incorporate an environmental component into products and services before they enter the production phase [Çinar H. 2005, p. 28]. That term is connected with another - 'eco-efficiency', which is seen both as a concept and as a tool where the basic idea is to produce more with less impact on nature, measured as reduced emissions or reduced raw material consumption, or both [Michelsen and Magerholm Fet 2010, p. 561] Other the most quoted definitions is from World Business Council for Sustainable Development (WBCSD) that defines eco-efficiency as 'the delivery of competitively priced goods and services that satisfy human needs and bring quality of life, while progressively reducing ecological impact and resource intensity throughout the life cycle, to a level at least in line with the Earth's estimated carrying capacity'.

In product development, the complexity of the decision process involving all environmental aspects very often creates an unbridgeable gap for designers. Every product damages the environment to some extent. Therefore, selection of materials, 
tools, technologies, and also an approach to design and manufacturing processes is a crucial factor in being environmentally friendly [Çinar H. 2005, p. 28]. Product development strategies capture the intensity of firms' innovation efforts within a technological domain, whereas process development strategies typically capture the intensity of innovation efforts aimed at increasing the efficiency and (or) the effectiveness of internal production processes [Branzei and Vertinsky 2006, p. 82]. There is a possibility on the phase of a new product development to introduce some factors oriented on improving the environmental profile of the product to both types of the strategy. They are so-called eco-design principles, possible solutions to improve the environmental profile of a product system, taking all the stages of its life cycle into consideration [van Hemel and Cramer 2002, p. 440]. Environmental factors should be taken into account at the earliest possible stage of product development and design [Çinar H. 2005, p. 27]. These eco-design principles, illustrated in Figure 1, are a priori clustered into eight eco-design strategies which arise as environmental answers to the environmental impacts detected in the previous Life Cycle Assessment (LCA) study (quantitative assessment) and from the eco-briefing (qualitative assessment) [González-García et al. 2012, p. 322].

Figure 1. The eco-design strategy wheel

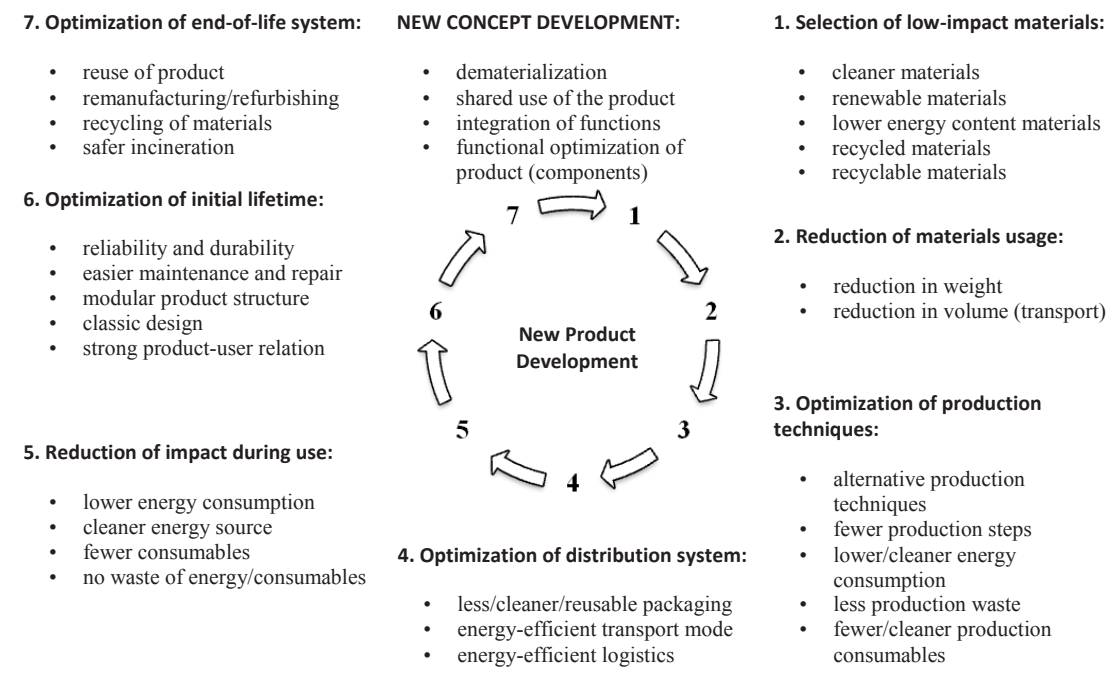

Source: Hemel and Cramer 2002, p. 441.

Hemel and Cramer [2002, p. 439] concluded that an eco-design improvement option only stands a chance, if it is supported by stimuli other than the expected environmental benefit alone. Those eco-design improvement options were most successful that were supported by several strong internal and external stimuli, and 
not blocked by any no-go barriers. The most influential internal stimuli were the opportunities for innovation, the expected increase of product quality and the potential market opportunities. The research revealed quite clearly that the most influential external stimuli for eco-design are 'Customer demands', 'Governmental legislation' and 'Industrial sector initiatives'. Nevertheless there were also the following barriers: 'No clear environmental benefit'; 'Not perceived as responsibility' and 'No alternative solution is available' (Figure 2).

Figure 2. The most influential stimuli and the most successful eco-design principles

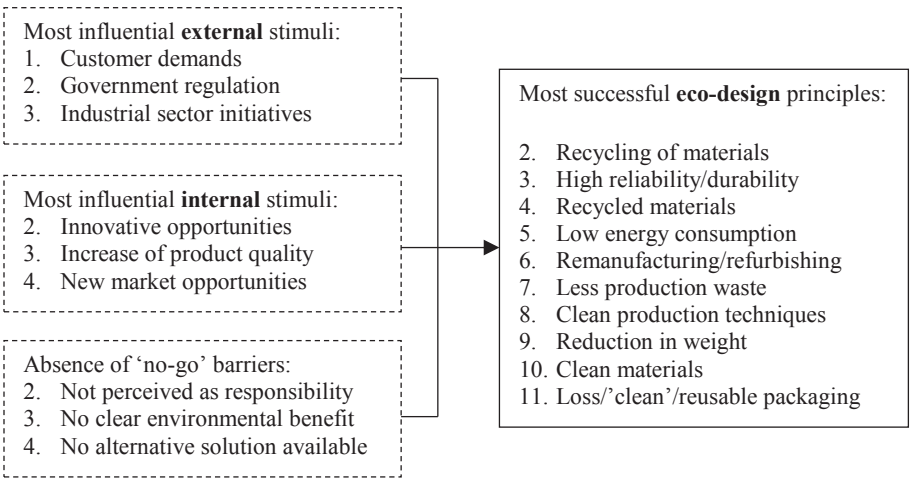

Source: Hemel and Cramer 2002, p. 453.

According to WBCSD [2006, p. 35, 65] in a global context eco-efficiency is integral to leading firms' business strategies, so if MSMEs want to compete on international markets, they should implement eco-approach in companies, especially as products designed to ecological design rules:

- can be cheaper to produce and use;

- can be smaller and simpler in their design;

- include a smaller variety of materials and are easier to disassemble for recycling;

- often they encompass higher functionality, better serviceability and easier upgradeability;

- can provide a higher value for their users, while the environmental influence related to their use is minimized.

After Plouffe et al. [2011, p. 578] it appears that MSMEs have a higher success rate of eco-designed products than large corporations, and also that the $\mathrm{B} 2 \mathrm{~B}$ sector is more sensitive to eco-designed products. Deutz et al. [2013, p. 124] indicate large companies appear to be more likely to include the environment principles at all stages of the design process than MSMEs. However, the difference is not statistically significant either by company size or whether they are consumer-interfacing. 
On the other hand large companies are significantly more likely than MSMEs to consider energy consumption in production, waste and pollution.

\section{Eco-design in MSME furniture industry}

In Polish furniture sector, micro-enterprises are the majority invariably for several years. The share of micro-firms remains permanently at the level of more than $90 \%$. That group of the furniture sector comprises mainly small family businesses with modest production scale. However number of such entities steadily decreases from 1998 for the benefit of medium and large enterprises. As a result, their participation in the production of the entire furniture industry is marginal and additionally regularly falling - from 21\% in 1995 to $\%$ in 2009 [BAA Polska 2011, pp. 14, 25]. That statistics indicates the need of finding the way of support for the family firms in the furniture industry.

Additionally the environmental awareness within the furniture industry has gradually increased during the last decade. The furniture manufacturers are exposed to an increasing demand for environmental information on the products, in particular from public purchasers. However, the MSMEs furniture manufacturers have faced some problems e.g. they do not have access to adequate tools and knowledge and resources to perform reliable environmental assessments [Michelsen and Magerholm Fet 2010, p. 563]. Although according to van Hamel and Cramer [2002, p. 453] for MSMEs even more important than technical problems, are economical and social factors like the acceptance of environmentally improved products in the market, and the way in which the MSMEs studied perceive the market perspectives of these products.

The furniture industry is basically an assembling industry, which employs different raw materials (not only wood but also fiber- and chipboards, metals, plastics, glass and leather) to manufacture different products. At the present time, the European furniture industry has a strong image worldwide thanks to its high level of quality, not only at a technical level, but also aesthetical. However, there is a growing concern about the environmental effects derived from goods production and use as well as on how they are disposed of at the end of their life cycle [GonzálezGarcía et al. 2012, p. 318].

Environmental impacts are quite limited for furniture during use but more associated with production and disposal. The requirements and criteria for furniture purchasing should be targeted to those environmental aspects that have the most influence and could, through eco-design, lead to the greatest environmental benefits [Parikka-Alhola K. 2008, p. 472]. Till now for the wood furniture industry, efforts have been focused on the study of different environmental properties of wood-based panels and their various finishes: volatile organic compounds (VOCs) in particleboard with diverse coverings; industrial surface coatings, including wood 
furniture and fixtures emission inventory development; emission factors for particleboard and medium density fiberboard; low speed impact on polyethylene and aramidic FRP laminates; ballistic simulation of impact on composite laminates; the use of manufacturing technologies of wood-based materials and coatings, and the mechanics and structure of wood-based composite materials. Other studies investigated formaldehyde emission from various wood composites such as the reduction of formaldehyde emission from plywood and particleboard made from various species based on manufacturing parameters [Çinar H. 2005, pp. 27-28; Parikka-Alhola K. 2008, p. 475].

The eco-design strategies identified by van Hemel and Cramer [2002] are not specific to furniture but more general in principle, applicable to any product as Parikka-Alhola [2008, p. 476] claims. Although there is no legislative pressure in the furniture sector, many manufacturers are becoming more aware of their responsibility to make more environmentally sound furniture. Environmental objectives in purchasing place pressure on designers to integrate environmental criteria into the production processes and the final product. Some of the most important decisions with respect to environmental properties of a new product are taken during the product development [Parikka-Alhola K. 2008, p. 473]. Product designers and procurement managers play a key role in a company. Their influence is not only crucial to product functionality and price. It also has a big effect on the environmental impact of production, product maintenance and disposal [Çinar H. 2005, p. 27; WBCSD 2006, p. 65]. Unfortunately often environmental considerations are competing with design criteria such as cost and need therefore to be established as a higher order consideration. Although what can be accomplished will depend on budget, viewing the environment as a design criterion limits rather than expands the possibilities considered. The utilization of a good design process seems fundamental [Bovea and Pérez-Belis, 2012, p. 61-70; Deutz et al. 2013, p. 127]. Nevertheless Parikka-Alhola [2008, p. 476 ] recognized several objectives for environmentally sound furniture:

- long lifetime (e.g. durability, adaptability, compatibility, timeless design, easy assembly and dismantling, easy caring and repairing, availability of spare parts and repair services);

- ecological profile of materials (e.g. lower chemical content, use of non-toxic substances, sustainable forestry, eco-labeled textiles, use of recycled material);

- environmentally sound packaging (e.g. reusable packages, packaging service system);

- recyclability (e.g. easy dismantling, recyclable materials, recyclable parts);

- environmentally sound production processes (e.g. low energy consumption, low production emissions and amount of chemicals).

Nowadays, furniture sector is paying special attention on environmental and innovative concerns due to the aim of distinguishing its products from other 
competitors as well as its entrance into the emerging market of green products [González-García et al. 2012, pp. 325]. Therefore on the basis of literature the most possible: requirements, opportunities and barriers for implementation of the ecodesign strategy in furniture family-owned MSMEs ware presented in Table 1. That will be the starting point for future research in the industry.

Table 1. Circumstances of implementing the eco-design strategy in furniture family-owned MSMEs

\begin{tabular}{|c|c|c|}
\hline \multicolumn{3}{|c|}{ ECO-DESIGN IN FURNITURE FAMILY-OWNED MSMEs } \\
\hline Requirements & Opportunities & Barriers \\
\hline $\begin{array}{l}\text { - economical and social fac- } \\
\text { tors like the acceptance and } \\
\text { competitiveness of environ- } \\
\text { mentally sound products on } \\
\text { the market } \\
\text { - finding alternative solutions } \\
\text { for technical problems } \\
\text { - use of certified wood from } \\
\text { 'sustainable forest' } \\
\text { - selection of substances, } \\
\text { materials and components, } \\
\text { prolongation of product life- } \\
\text { time and creation of products } \\
\text { that consume less energy } \\
\text { during their lifetime and are } \\
\text { recyclable or reusable after the } \\
\text { use phase } \\
\text { - intension of establishing a } \\
\text { competitive advantage from } \\
\text { the eco-design } \\
\text { - integration of the work and } \\
\text { external environment con- } \\
\text { centrating on ergonomics, } \\
\text { security, stability and strength, } \\
\text { user friendliness, material } \\
\text { characteristics, emissions and } \\
\text { ecology } \\
\text { • necessity of integration the } \\
\text { eco-strategy in the company } \\
\text { management system } \\
\text { - compatibility the eco-design } \\
\text { strategy with other corporate } \\
\text { strategies }\end{array}$ & $\begin{array}{l}\text { - pressing social needs and } \\
\text { consumer demand for envi- } \\
\text { ronmentally sound products } \\
\text { - promotion of sustainable } \\
\text { development in the furniture } \\
\text { industry } \\
\text { - developing an approach } \\
\text { to environmental manage- } \\
\text { ment that takes account of } \\
\text { particular cultural needs and } \\
\text { capabilities } \\
\text { - education and training of } \\
\text { society } \\
\text { - engagement the community } \\
\text { and workers (local community } \\
\text { activism) } \\
\text { - more training and govern- } \\
\text { ment assistance } \\
\text { - development of low-cost, ef- } \\
\text { fective certification systems } \\
\text { - new sources of eco-project } \\
\text { finance } \\
\text { - making the certification } \\
\text { process and environmental } \\
\text { management systems more } \\
\text { widely available } \\
\text { - greater access to information } \\
\text { - leap-frog technology } \\
\text { - cooperation with large com- } \\
\text { panies }\end{array}$ & $\begin{array}{l}\text { - limited finances of MSMEs } \\
\text { f macroeconomic policies that } \\
\text { favor environmentally un- } \\
\text { friendly practices } \\
\text { - lack of public procurement } \\
\text { - limited regulations enforce- } \\
\text { ment limited environmental } \\
\text { infrastructure (e.g. places to } \\
\text { dispose of waste) } \\
\text { - necessity of adapted the } \\
\text { eco-efficiency solutions to } \\
\text { local conditions (cultural and } \\
\text { economic) } \\
\text { - "informality" of many } \\
\text { MSMEs (often they don't pay } \\
\text { taxes) } \\
\text { - not perceived taking care of } \\
\text { environment as responsibility } \\
\text { - no clear environmental } \\
\text { benefit } \\
\text { - no alternative solution (e.g. } \\
\text { technological) available or too } \\
\text { expensive equivalents } \\
\text { - lack of materials about an } \\
\text { ecological profile } \\
\text { - weak access to information } \\
\text { and research results } \\
\text { - uncertain economic return } \\
\text { of an eco-design approach }\end{array}$ \\
\hline
\end{tabular}




\begin{tabular}{|c|c|c|}
\hline \multicolumn{3}{|c|}{ ECO-DESIGN IN FURNITURE FAMILY-OWNED MSMEs } \\
\hline Requirements & Opportunities & Barriers \\
\hline $\begin{array}{l}\text { - specific interpretation of } \\
\text { the eco-design strategy by } \\
\text { the company and consistent } \\
\text { implementation } \\
\text { - supporting to close material } \\
\text { cycles with reused materials, } \\
\text { or not using certain harmful } \\
\text { substances, to meet the pur- } \\
\text { chasers' interests } \\
\text { - monitoring data about en- } \\
\text { vironmental policy, pollution } \\
\text { emissions, waste materials } \\
\text { from the manufacturing pro- } \\
\text { cess, materials used (material } \\
\text { specification), the waste-han- } \\
\text { dling of materials used in the } \\
\text { product, and environmentally } \\
\text { classified materials/chemicals } \\
\text { - raising concern about the } \\
\text { emissions of chemical sub- } \\
\text { stances from the material } \\
\text { during its utilization } \\
\text { - conditions (furniture manu- } \\
\text { facturing processes, materials } \\
\text { and chemicals in the finished } \\
\text { products, recycling properties } \\
\text { of the products, quality, regu- } \\
\text { latory and social performance } \\
\text { criteria) of certification ob- } \\
\text { tainment from the eco-labels } \\
\text { institutions }\end{array}$ & $\begin{array}{l}\text { - MSMEs work with supply } \\
\text { chains, neighbor companies } \\
\text { - creation environmental im- } \\
\text { provement and generation in- } \\
\text { formation that allow MSMEs } \\
\text { to demonstrate improvements } \\
\text { to the market (i.e. ISO) } \\
\text { - generation home country } \\
\text { demand through fostering en- } \\
\text { vironmental technologies that } \\
\text { anticipate market demands } \\
\text { and requirements by industry } \\
\text { and government } \\
\text { - requirement of improved } \\
\text { environmental performance } \\
\text { by financing institutions and } \\
\text { insurers } \\
\text { - fundamental environmental } \\
\text { and public health problems } \\
\text { - environmental aspects are } \\
\text { taken into consideration in the } \\
\text { public procurement process } \\
\text { (e.g. purchase of office furni- } \\
\text { ture) } \\
\text { - taking benefit from other } \\
\text { countries' experience } \\
\text { - enhance the firm's image and } \\
\text { improve relationships with } \\
\text { various stakeholders: financial, } \\
\text { environmental groups, neigh- } \\
\text { boring communities } \\
\text { - foster greater creativity or } \\
\text { enhance innovation capability }\end{array}$ & \\
\hline
\end{tabular}

Source: Own studies based on Adamczyk, W. 2004, pp. 63-74; WBCSD [2006, p. 35-36]; Parikka-Alhola K. 2008, p. 482; Plouffe et al. 2011, p. 574-579.

\section{Conclusions}

Growing environmental concerns during the last decades, coupled with public pressure and stricter regulations, are changing the way people do business across the world. Results of conducted study indicates that in furniture family-owned 
MSMEs there is a set of requirements, opportunities and barriers connected with the eco-design strategy that support this approach or not. Nevertheless the one is inevitable - consumers are becoming increasingly conscious about the products, and some of requirement about the product slowly come into standards. Moreover more and more organizations begin to behave in an environmentally responsible manner. That is the reason why furniture designers or manufacturers also should be aware of the consequence of their work and consider its impact on the environment. Not too far in the future, "green" design might be as expected in project solutions as universal design is today. For Polish furniture family-owned MSMEs it could be the way enabling them to compete on the global markets so it is important to continue this research in the future.

\section{Bibliography}

Adamczyk, W. (2004) Ekologia wyrobów, Warszawa: Polskie Wydawnictwo Ekonomiczne.

Bovea, M.D., Pérez-Belis, V. (2012) 'A taxonomy of ecodesign tools for integrating environmental requirements into the product design process', Journal of Cleaner Production, no. 20, pp. 61-71.

Branzei, O., Vertinsky, I. (2006) 'Strategic pathways to product innovation capabilities in SMEs', Journal of Business Venturing, no. 21, pp. 75-105.

Carlson D. S., Upton N., Seaman S. (2006) 'The impact of human resource practices and compensation design on performance: an analysis of family-owned SMEs', Journal of Small Business Management, vol. 44, no. 4, pp. 531-543.

Çinar H. (2005) 'Eco-design and furniture: Environmental impacts of wood-based panels, surface and edge finishes', Forest Products Journal, vol. 55, no. 11, pp. 27-33.

Deutz, P., McGuire M., Neighbour, G. (2013) 'Eco-design practice in the context of a structured design process: an interdisciplinary empirical study of UK manufacturers', Journal of Cleaner Production, no. 39, pp. 117-128.

González-García, S., García Lozano, R., Moreira, M. T., Gabarrell, X., Rieradevall i Pons, J., Feijoo, G., Murphy, R. J. (2012) 'Eco-innovation of a wooden childhood furniture set: An example of environmental solutions in the wood sector', Science of the Total Environment, no. 426, pp. 318-326.

Grupa Doradców Biznesowych BAA Polska (2011) 'Sektor meblarski w czasie i przestrzeni. Ocena standingu adaptacyjności sektora', raport opracowany w ramach projektu 'Branżowi Liderzy Zmian'.

Grzegorzewska, E. (2013) 'The influence of global economic crisis on import and export of furniture in Poland', Annals of Warsaw University of Life Sciences - SGGW. Forestry and Wood Technology, no. 82, pp. 308-312.

Grzegorzewska E., Olkowicz M. (2013) 'Determinanty realizacji procesu rozwoju nowych mebli w sektorze MŚP’, Firmy Rodzinne - wyzwania globalne i lokalne, Przedsiębiorczość $i$ Zarzadzanie/Spoteczna Akademia Nauk, vol. 14, no. 6, part 1, pp. 299-311. 
Hemel, C., Cramer, J. (2002) 'Barriers and stimuli for ecodesign in SMEs', Journal of Cleaner Production, no. 10, pp. 439-453.

Hoffman, K., Parejo, M., Bessant, J., Perren, L., (1998) 'Small firms, R\&D, technology and innovation in the UK: a literature review', Technovation, vol. 18, no.1, pp. 39-55.

Kaufmann, A., Tödtling, F. (2002) 'How effective is innovation support for SMEs? An analysis of the region of Upper Austria', Technovation, no. 22, pp. 147-159.

Lassen, P., Kunde, J., Gioia, C. (2008) 'Creating a clearly differentiated SME brand profile: The case of Montana A/S', Brand Management, vol. 16, no. 1-2, August-October, pp. 92-104.

Lindman, M., Scozzi, B., Otero-Neira, C. (2008) 'Low-tech, small- and medium-sized enterprises and the practice of new product development - an international comparison', European Business Review, vol. 20, no. 1, pp. 51-72.

Michelsen, O., Magerholm Fet, A. (2010) 'Using eco-efficiency in sustainable supply chain management; a case study of furniture production', Clean Technologies and Environmental Policy, no. 12, pp. 561-570.

Olkowicz, M., Szymanowski, W. (2012) 'The practice of the new product development in SME and large furniture enterprises' Annals of Warsaw University of Life Sciences - SGGW. Forestry and Wood Technology, no. 79, pp. 118-122.

Otero-Neira, C., Lindman, M. T., Fernández, M. J. (2009) 'Innovation and performance in SME furniture industries - an international comparative case study', Marketing Intelligence \& Planning, vol. 27, no. 2, pp. 216-232.

Parikka-Alhola, K. (2008) 'Promoting environmentally sound furniture by green public procurement', Ecological Economics, no. 68, pp. 472-485.

Plouffe, S., Lanoie, P., Berneman, C., Vernier, M. F. (2011) 'Economic benefits tied to ecodesign' Journal of Cleaner Production, no. 19, pp. 573-579.

Polish Agency for Enterprise Development (2009)'Family Businesses and the Polish EconomyOpportunities and Challenges', Warsaw, PAED.

Trigkas, M., Papadopoulos, I., Karagouni, G. (2012) 'Economic efficiency of wood and furniture innovation system', European Journal of Innovation Management, vol. 15, no. 2, pp. 150-176.

World Business Council for Sustainable Development (WBCSD), (2006) 'Eco-efficiency learning module, Five Winds International and WBCSD. 